\title{
MANAJEMEN SEKOLAH DALAM MEWUJUDKAN SEKOLAH SEHAT DI SMP ISLAM CENDEKIA CIANJUR (SICC) BOARDING SCHOOL
}

\author{
Herlina $^{a)}$, Rita Retnowati ${ }^{\left.b^{*}\right)}$, Griet Helena Laihad ${ }^{b)}$ \\ a) SMP PGRI Tugu 207 Cisarua, Bogor, Indonesia \\ ${ }^{b)}$ Universitas Pakuan, Bogor, Indonesia \\ *)e-mail korespondensi: rita.retnowati@unpak.ac.id
}

\begin{abstract}
Abstrak. Penelitian ini bertujuan untuk memperoleh gambaran berdasarkan fakta berupa data dan informasi mengenai manajemen sekolah SMP Islam Cendekia Cianjur (SICC) Boarding School dalam mewujudkan sekolah sehat. Metode penelitian kualitatif digunakan untuk menghasilkan paparan yang komprehensif mengenai langkah-langkah manajerial, mulai dari perencanaan, pengorganisasian, pelaksanaan, dan pengendalian. Dengan menggunakan alat dan tehnik pengumpulan data melalui wawancara, dokumentasi, dan observasi memperoleh hasil bahwa: 1) Perencanaan sekolah sehat di SICC Boarding School di lakukan di awal pendiriannya dengan tahap awal lebih fokus ke pengadaan dan kelengkapan unit kesehatan sekolah (UKS), 2) Pengorganisasian sekolah sehat merupakan wewenang kepala sekolah. Namun, dalam pelaksanaannya program sekolah sehat ini dibantu oleh beberapa personil, seperti koordinator sekolah sehat, pembina UKS, bendahara UKS dan anggota, 3) Pelaksanaan manajemen sekolah sehat dilaksanakan oleh koordinator sekolah sehat dan tim lainnya yang ada di struktur organisasi. Konsep sekolah sehat di SICC Boarding School ini lebih mengembangkan program unggulan dari UKS, yaitu TRIAS UKS, pembiasaan PHBS, dan pengadaan sarana dan prasarana UKS. 4) Pengendalian dilakukan dengan monitoring dan evaluasi yang dilakukan langsung oleh kepala sekolah sebagai ketua dari struktur organisasi UKS. Pengendalian di fokuskan pada tiga aspek yaitu SDM terutama para tim sekolah sehat, Program kerja sekolah sehat dan Pengadaan sarana prasarana UKS. Berdasarkan hasil penelitian dapat disimpulkan bahwa manajemen sekolah berjalan dengan baik dengan mengacu pada kondisi dan kebutuhan sekolah dan dapat dijadikan rujukan model untuk sekolah boarding lainnya.
\end{abstract}

Kata Kunci: manajemen sekolah, sekolah sehat, UKS.

\section{SCHOOL MANAGEMENT IN REALIZING HEALTHY SCHOOLS IN SMP ISLAM CENDEKIA CIANJUR (SICC) BOARDING SCHOOL}

\begin{abstract}
This researched aimed to have comprehensive findings based on factual datas and information about school management at SMP Islam Cendekia Cianjur (SICC) Boarding School interms in actualizing healthy school. The qualitative method was used in order to have a comprehensive description as an output about all managerial steps; planning, organizing, actuating, and evaluating the school management at SMP Islam Cendekia Cianjur (SICC) Boarding School. All data was collected by indept interview, observation and documentation, showed that: 1) Planning for healthy school at the SICC Boarding School was issued at the beginning of its establishment with the initial stage, focusing more on procurement and completeness of school medical room (UKS), 2) Organizing health schools is the authority of the principal where the implementation of this healthy school program is assisted by several personnel, the coordinator of healthy school , UKS builder, financial staff and the members, 3) Implementing of healthy school management is carried out by healthy school coordinators and other teams in the organizational list. The concept of healthy school at the SICC Boarding School is to develop superior programs from UKS, it is called UKS TRIAS, PHBS habituation, and the procurement of facilities and infrastructure for UKS, 4) Controlling is carried out by monitoring and evaluating directly by school principal as the chairman of the UKS organizational list. The Controlling is focused on three aspects; human resources focused on healthy school teams, the healthy school programme, and the procurement tools of UKS. Based on the results of the study, it is concluded that school management runs well with referring to the conditions and needs of school andcan be used as a reference model for other boarding school as well.
\end{abstract}

Keywords: School management, healthy school, UKS

\section{PENDAHULUAN}

Pendidikan memiliki peran yang sangat penting dimana melalui pendidikan orang-orang dapat mengoptimalkan bakat dan kemampuan yang mereka miliki. Dalam pengembangan bakat dan kemampuannya, peserta didik dipengaruhi oleh beberapa faktor, mulai dari proses KBM (kegiatan Belajar Mengajar) yang dijalankan di sekolah, tenaga pengajar yang prefesional juga dari faktor sarana dan prasarana. Lingkungan pendidikan yang bersih dan sehat menjadi salah satu penunjang keberhasilan proses KBM di sekolah. Oleh karena itu pemerintah mencanangkan program sekolah sehat demi terciptanya suasana kondusif saat pembelajaran, dan meningkatkan derajat kesehatan bagi warga sekolah. 
Berdasarkan Undang-undang Nomor 23 Tahun 1992 Pasal 45 Tentang Kesehatan Sekolah ditegaskan bahwa program Kesehatan Sekolah diselenggarakan untuk meningkatkan kemampuan hidup sehat peserta didik dalam lingkungan hidup sehat sehingga peserta didik dapat belajar, tumbuh dan berkembang secara harmonis dan optimal sehingga diharapkan dapat menjadikan sumber daya manusia yang berkualitas. Selain itu menurut Mendiknas (pada Pembukaan Rakernas UKS ke IX 2008, Bali) sekolah sebagai tempat belajar, tidak saja hanya perlu memiliki lingkungan bersih dan sehat, yang mana mendukung berlangsungnya proses belajar dan mengajar yang baik namun, diharapkan mampu menjadikan siswa memiliki derajat kesehatan yang lebih baik. Lingkungan sekolah sehat, tentu akan sangat mendukung pencapaian tujuan pendidikan.

Jelas sekali keuntungan dari terprogramnya sekolah sehat yaitu dimana kegiatan ini dapat menjadikan lingkungan sekolah tertata baik dan bersih. Kondisi ini akan mampu menciptakan suasana belajar yang kondusif yang pada waktunya nanti akan meningkatkan semangat belajar dan prestasi belajar, termasuk di dalamnya kemandirian, jiwa kemandirian, enterpreneurship dan kreativitas, serta membentuk masyarakat yang sadar kesehatan.

Pemerintah mengeluarkan kebijakan sebagai upaya untuk meningkatkan kesehatan siswa dengan program Sekolah Sehat. Sekolah sehat adalah sekolah yang berhasil membantu peserta didik unggul secara optimal dengan mengedepankan aspek kesehatan. Sekolah sehat selalu berusaha membangun kesehatan jasmani dan kesehatan rohani melalui pemahaman, kemampuan, dan perilaku yang bertanggung jawab (Zubaidah dkk., 2017: 99). Hermien (2018: 87) mengungkapkan Sekolah Sehat adalah sekolah yang berhasil membantu peserta didik unggul secara optimal dengan mengedepankan aspek kesehatan. Dengan kata lain, sekolah sehat selalu berusaha membangun kesehatan jasmani dan kesehatan rohani melalui pemahaman, kemampuan, dan perilaku yang bertanggung jawab, pengambilan keputusan terbaik untuk terciptanya kesehatan secara mandiri dapat diwujudkan.

Sekolah adalah merupakan lembaga pendidikan formal yang secara sistematis melaksanakan program bimbingan, mengajar, dan latihan dalam rangka membantu siswa agar mampu mengembangkan potensinya, baik yang menyangkut aspek moral, spiritual, intelektual, emosional, maupun sosial (Yusuf, 2001: 51). Lain pula yang disampaikan oleh Erawan (2015: 44) dalam teorinya yang menyatakan kesehatan sebagai suatu keadaan tentang kebahagiaan yang sempurna baik secara fisik, mental dan sosial.

Dari uraian di atas dapat disimpulkan bahwa sekolah sehat adalah sekolah yang memiliki lingkungan belajar yang sehat secara jasmani dan rohani yang ditandai dengan situasi lingkungan sekolah yang bersih, indah, tertib, dan perilaku hidup sehat dari seluruh komponen sekolah.

Muhamad dkk. (2017:28) menyatakan bahwa manajemen merupakan alat atau perangkat yang harus benar-benar dipahami oleh kepala sekolah dalam mengelola sumber daya yang dimiliki secara efektif dan efisien untuk mencapai tujuan yang telah ditetapkan. Sepak terjang manager dalam mengelola sumber daya di dalam sekolah akan sangat tergantung pada kompetensi (skill) kepala sekolah itu sendiri. Menurut Tim Dosen AP UPI (2013: 151), manajemen merupakan suatu proses tertentu yang menggunakan kemampuan atau keahlian untuk mencapai suatu tujuan yang di dalam pelaksanaanya dapat mengikuti alur keilmuan secara illmiah dan dapat pula menonjolkan kekhasan atau gaya manajer dalam mendayagunakan kemampuan orang lain.

Menurut Handoko (2012: 45) manajemen adalah melakukan pekerjaan dengan orang-orang yang menentukan, menginterpretasikan dan mencapai tujuan-tujuan organisasi dengan pelaksanaan fungsi manajemen. Adapun Faktor-faktor yang dijabarkan berupa lima fungsi manajemen yaitu : 1) Perencanaan (planning), 2) Pengorganisasian (organizing), 3) kepegawaian (staffing ), 4) pengarahan dan kepemimpinan (leading), (5) Pengawasan (controlling). Yanuar (2011: 67) menyatakan bahwa manajemen sekolah adalah proses yang dilakukan pimpinan instansi dalam membimbing penyelenggaraan dan pelaksanaan pekerjaan sekolah, dimana sekolah tersebut sebagai organisasi untuk mewujudkan tujuan pendidikan dan tujuan sekolah yang telah ditetapkan. Pendapat Suryosubroto (2010: 51) menyatakan bahwa pengorganisasian adalah suatu kegiatan yang memberikan pembagian tugas-tugas kepada orang yang telibat dalam kerja sama untuk mencapai tujuan yang telah ditentukan. Menurut Kristiawan (2017:48) pelaksanaan adalah hubungan antara aspek-aspek individual yang ditimbulkan oleh adanya hubungan terhadap bawahan untuk dapat dimengerti dan memahami pembagian pekerjaan yang efektif dan efisien. Akan adanya peningkatan nilai budaya organisasi dengan meningkatkan sikap profesional manusianya (Suchyadi, 2017).

Dari uraian di atas dapat disimpulkan bahwa manajemen sekolah adalah suatu proses kerjasama dalam merencanakan (planning), mengorganisasi (organizing), melaksanakan (actuating), dan mengendalikan (controlling) sekolah dengan sistematik dan komprehensif dalam rangka mewujudkan tujuan pendidikan nasional.

\section{METODE PENELITIAN}

Pada penelitian ini, untuk menyajikan respons-respons dan perilaku subjek, strategi pengumpulan data dilakukan dengan pengumpulan dokumen, pengamatan berperan serta, wawancara terstruktur dan tidak terstruktur maupun informal, mencatat data dalam catatan lapangan secara intensif. Teknik pengumpualn data yang digunakan oleh si peneliti diperkuat dengan melakukan telaah kepustakaan. Pengkajian secara mendalam merupakan ciri khas dan sekaligus menjadi faktor keunggulan dari metode kualitatif. Metode penelitian kualitatif berupaya memahami suatu fenomena atau kejadian yang kompleks yang ada pada objek penelitian. Proses pengumpulan data dilakukan secara terus menerus dan intensif dengan sebanyak-banyaknya dan selengkap mungkin dari para informan atau nara sumber yang kemudian data tersebut akan di analisis 
dan dideskripsikan, sehingga akan menghasilkan interpretasi secaar mendalam, yang akan dituangkan dalam bentuk laporan penelitian secara tertulis.

\section{HASIL DAN PEMBAHASAN}

Temuan hasil penelitian berdasarkan analisis antar situs terhadap empat sub fokus penelitian yang diperoleh melalui wawancara, observasi, dan studi dokumentasi kepada delapan informan di SICC Boarding School dijabarkan sebagai berikut:

\section{Sub Fokus 1 : Perencanaan manajemen sekolah dalam mewujudkan sekolah sehat.}

Setelah dilakukan pembahasan di bab sebelumnya didapatkan hasil pokok yang dapat dianalisis sebagai berikut. Keseluruhan proses dan prosedur manajemen sekolah dalam mewujudkan sekolah sehat merupakan faktor pokok dalam manajemen sekolah serta pengelolaan program pendidikan untuk pengembangan sekolah sehat. Setiap tahapan manajemen yang berlaku di SICC Boarding School telah memuat komponen-komponen yang sesuai dengan konsep pada masing-masing fungsi dasar manajemen. Pada tahap perencanaan disusun sebagai langkah paling awal yang disesuaikan dengan fakta kebutuhan dan kondisi yang ada dilingkungan sekolah. Perencanaan merupakan suatu proses awal yang sistematis yang merancang seluruh komponen organisasi yang ada untuk dipersiapkan agar langkah ini dapat menunjang proses kegiatan organisasi dalam mencapai tujuan yang diharapkan. Hal ini sesuai dengan teori yang disebutkan oleh Yanuar (2011: 67) menyatakan bahwa manajemen sekolah adalah proses yang dilakukan pimpinan instansi dalam membimbing penyelenggaraan dan pelaksanaan pekerjaan sekolah, dimana sekolah tersebut sebagai organisasi untuk mewujudkan tujuan pendidikan dan tujuan sekolah yang telah ditetapkan.

Berdasarkan pelaksanaan program sekolah sehat yang berjalan di SICC Boarding School, maka sebelumnya disusun perencanaan program sekolah sehat sebagai berikut:

1. Konsep sekolah sehat SICC Boarding School adalah konsep sekolah sehat yang mempunyai kekhususan yang dikembangkan sendiri, SICC Boarding School salah satu sekolah SMP terpadu yang berbasis pesantren (boarding) yang memililki keberanian untuk mewujudkan sekolah sehat. Sekolah mengacu pada kebijakan-kebijakan yang menjadi dasar dari pelaksanaan program sekolah diantaranya Undang-Ungang No.23 Tahun 1992 pasal 45, SKB 4 Menteri, motto sekolah dan visi misi UKS. tahap awal dimulai dariPenyusunan program sekolah sehat mulai dari pengadaan sarana prasarana, terutama ruangan UKS yang lengkap, sekolah menyiapkan semuanya mengacu pada visi misi UKS dan standar sekolah sehat yang ditentukan oleh pemerintah.

2. Penyusunan program sekolah sehat SICC Boarding School dibuat dengan langkah awal menyiapkan pengadaan fasilitas UKS yang lengkap sesuai dengan syarat dan ketentuan dari pemerintah. Bekerja sama dengan beberapa pihak instansi luar sekolah seperti puskesmas, dinas kesehatan, rumah sakit, dll. Adapun langkah-langkah perencanaan program sekolah sehat yang telah dijalankan sebagai berikut :

a. Menetapkan sasaran dan tujuan program sekolah sehat

b. Menetapkan pedoman pada visi misi UKS

c. Menyeleksi para SDM yang berkompeten di program sekolah sehat

d. Membuat struktur organisasi UKS

e. Membuat program kerja tahunan UKS

f. Membuat perencanaan anggaran pengembangan UKS

g. Melengkapi pengadaan fasilitas UKS sesuai standar dan ketentuan dari pemerintah

h. Merumuskan aturan dan tata tertib khusus dalam program sekolah sehat

i. Menyiapkan program-program UKS untuk persiapan mengikuti lomba antar sekolah, kecamatan dan kabupaten bahkan tingkat provinsi dan tingkat nasional.

3. Penetapan visi misi UKS tidak dilakukan oleh pihak sekolah, semuanya sudah ditetapkan dari pemerintah. Dalam hal ini para personil yang terlibat di struktur organisasi menyiapkan dan membuat program kerja tahunan unit kesehatan sekolah (UKS). Program yang dibuat khusus mengacu pada program unggulan UKS yaitu TRIAS UKS, diantaranya program kegiatan pendidikan kesehatan, program pelayanan kesehatan, dan program pembinaan lingkungan sekolah sehat. Masingmasing program inti ini memiliki beberapa program pilihan yang akan dilaksanakan selama 1 tahun. Semua kegiatan dijabarkan secara jelas jenis kegiatan nya mulai dari waktu pelaksanaan dan juga tim pelaksananya. Adapun tujuan dari program sekolah sehat ini agar sekolah memiliki pengakuan positif dari masyarakat dan meningkatkan minat para peserta didik baru untuk bersekolah di SICC Boarding School.

4. Koordinator sekolah sehat diberikan keleluasaan dalam menyusun program kerja UKS sampai dengan pelaksanaan programprogram tersebut. Dalam pelaksanaan program sekolah sehat ini koordinator dibantu oleh pembina UKS, bendahara UKS dan anggota, seperti bidan desa, ketua bank sampah sindanglaka, wali asrama dan KKR. Semua program yang dibuat dan di susun masing-masing memiliki tim penanggung jawabanya misalnya untuk kegiatan latihan mingguan PMR akan ditangani oleh pembina PMR, KKR dan duta go green. Semua diharapkan dapat bekerja sama dengan baik dan setiap program dapat terlaksana dengan optimal agar sekolah dapat mewujudkan sekolah sehat tingkat nasional.

5. Pelaksanaan utama di awal dalam program sekolah sehat ini diantaranya melaksanakan kegiatan program UKS SMP Islam Cendekia Cianjur (SICC) yaitu yang pertama fokus pada unsur SDM yang menjadi warga sekolah dengan menerapkan 
pembiasaan PHBS (pola hidup bersih dan sehat). Dalam pembiasaan ini tim UKS mencoba memasukan materi PHBS agar menjadi budaya dalam kehidupan sehari-hari yaitu kurikulum tidak tersurat selama 5 menit di setiap mengawali pembelajaran. Selain itu aplikasinya juga dilihat setiap hari, mulai dari pemantauan kebersihan yang dilakukan oleh seluruh warga sekolah ke asrama-asrama setiap pulang sekolah serta di masukkannya ke dalam kegiatan kedisiplinan. Pelaksanaan program yang kedua yaitu fokus pada fisik UKS, dalam kegiatan ini sekolah mengutamakan pada pengadaan dan pemenuhan sarpras untuk UKS dan lingkungan sekitar dalam mengembangkan UKS, khususnya SMP I Cendekia Cianjur (SICC) sudah bekerja sama dengan beberapa intansi terkait. Selain itu juga UKS membuat program-program baru untuk diterapkan di siswa, dengan berbasis kepada lingkungan, sosial dan kemanusiaan. Program ini dilaksanakan oleh 4 divisi khusus dari UKS.

\section{Sub Fokus 2; Pengorganisasian manajemen sekolah dalam mewujudkan sekolah sehat}

Tahap pengorganisasian di SICC Boarding School dalam program sekolah sehat mengklasifikasikan dan menata setiap potensi sumber daya yang ada di sekolah untuk diberi tanggung jawab dan saling bekerjasama sesuai dengan peran masingmasing. Hal ini sesuai dengan pendapat Suryosubroto (2010: 51), bahwa pengorganisasian adalah suatu kegiatan yang memberikan pembagian tugas-tugas kepada orang yang telibat dalam kerja sama untuk mencapai tujuan yang telah ditentukan.

Berdasarkan perencanaan yang telah ditetapkan pada manajemen sekolah dalam pengembangan program sekolah sehat, maka disusun pengorganisasian (organizing) sebagai berikut :

1. Struktur organisasi dan pembagian tugas pada program sekolah sehat disusun ke dalam bagan struktur organisasi yang menggambarkan hirarki wewenang dari kepala sekolah ke bawah. Masing-masing jabatan memiliki tugas dan wewenang yang berbeda, baik secara administratif maupun capaian kinerja. Struktur organisasi paling tinggi yaitu ketua, yang diduduki oleh kepala sekolah, diikuti stuktur dibawahnya yaitu koordinator sekolah sehat, yang membawahi juga pembina UKS dan bendahara serta para anggota. Struktur yang dibentuk berdasarkan pada kebutuhan program yang dijalankan dan menyesuaikan dengan program UKS yang dijalankan. Masing- masing personil bertanggung jawab sesuai dengan tupoksi nya masing-masing. Pemberian SK pun di berikan kepada para personil yang terpilih agar dalam pelaksanaan tugasnya lebih disiplin dan penuh tanggung jawab.

2. Bentuk dari struktur organisasi yang dibuat untuk program sekolah sehat ini sangat simple berbentuk piramidal, dimulai dari kepala sekolah sebagai pihak penanggung jawab utama yang membawahi koordinator sekolah sehat. Pihak koordinator sekolah ini terdiri dari satu orang, personilnya ditunjuk dari kalangan guru yang berkompeten di bidang sekolah sehat. Pada posisi koordinator itu sendiri terpilih dari guru mata pelajaran IPA, guru ini sudah mendapatkan sertifikat khusus pelatihan Guru Unit Kesehatan Sekolah (UKS) dari Dinas Kesehatan Kabupaten Cianjur. Dari pihak koordinator sekolah sehat langsung mengatur secara fokus semua program sekolah sehat dibantu juga dengan tim UKS yang terdiri dari penasehat, pembina, sekretaris, bendahara dan juga dibantu oleh para anggota seperti bidan Desa, KKR dan wali asrama.

3. Pihak sekolah dalam hal ini kepala sekolah memberikan wewenang penuh kepada para personil yang terlibat dalam program sekolah sehat, khususnya pada koordinator sekolah dan tim UKS lainnya. Setiap sumber daya manusia yang difungsikan dalam pengelolaan program sekolah sehat di SICC Boarding School ini merupakan personil-personil yang berkompeten pada bidangnya. Koordinator sekolah sehat dan tim UKS dituntut mampu melakukan kerja sama yang baik dan mengerjakan setiap tugas dengan maksimal. Penyusunan program sekolah sehat dan pelaksanaanya dapat berjalan dengan baik sesuai dengan rencana.

4. Koordinator Sekolah Sehat (KSS) dibantu juga oleh pembina UKS dalam pelaksanaan program sekolah sehat, dimana tugasnya di sini adalah ikut menyusun program kerja Unit Kesehatan Sekolah (UKS) dan mengawasi setiap pelaksanaan program sekolah sehat. Di bawah pembina UKS ini terdapat pula sposisi sekretaris, bendahara dan juga para anggota KKR yang membantu pelaksanaan program sekolah sehat di SICC Boarding School. Mereka semua di struktur organisasi memiliki posisi yang berbeda, namun sama-sama memiliki tanggung jawab yang sama dalam mewujudkan program sekolah sehat.

5. Alur koordinasi yang ada di struktur organisasi sekolah sehat sejauh ini berjalan dengan baik, sesuai dengan posisi yang ada di struktur. Komunikasi dari pihak atas yaitu kepala sekolah sampai kebagian bawah terjalin sangat komunikatif dan terbuka. Setiap informasi dalam bentuk apapun akan selalu tersampaikan dengan baik. Masing-masing aktif dalam membina hubungan kerja demi terwujudnya sekolah sehat di SICC Boarding School.

\section{Sub Fokus 3: Pelaksanaan program sekolah sehat}

Tahap pengarahan dan pelaksanaan pada manajemen sekolah SICC Boarding School di dasarkan pada keselarasan dan kesepakatan antar sumber daya manusia (SDM) yang ada di sekolah sesuai dengan perencanaan sehingga pada penentuan dan pemilihan para personil ini menjadi arahan kerja dalam pencapaian tujuan sekolah. hal ini sejalan dengan pendapat Kristiawan (2017:48) pelaksanaan adalah hubungan antara aspek-aspek individual yang ditimbulkan oleh adanya hubungan terhadap bawahan untuk dapat dimengerti dan memahami pembagian pekerjaan yang efektif dan efisien. Actuating di sini merupakan intisari dari manajemen, karena secara khusus berhubungan dengan orang-orang.

Berdasarkan pengorganisasian yang telah ditetapkan pada manajemen sekolah dalam mewujudkan sekolah sehat, maka disusun pelaksanaan (Actuating) sebagai berikut:

1. Alur pendelegasian wewenang dimulai dari top management yaitu kepala sekolah sebagai ketua di struktur organisasi UKS yang diturunkan langsung ke bawahnya. Pendelegasian wewenang dari kepala sekolah akan disampaikan kepada masing- 
masing staf yang ada dibawahnya seperti koordinator sekolah sehat dan pembina UKS, yang selanjutnya diteruskan ke bendahara serta para anggota.

2. Upaya kepala sekolah dalam melaksanakan tugasnya sangat jelas sekali menerapkan semua perannya dengan baik, mulai dari sebagai educator, manager,leader, bahkan motivator. Dan hal ini diterapkan pula di struktur organisasi UKS, di mana kepala sekolah diposisikan sebagai ketua yang menjadi pimpinan tertinggi di struktur organisasi. Pengarahan yang tepat kepada para stafnya dilakukan untuk menggerakan para personil dalam melaksanakan tugas-tugasnya secara profesional dan bertanggung jawab. Pengarahan dilakukan mulai dari awal pelaksanaan program sekolah sehat, bahkan di saat pelaksanaan suatu kegiatan berlangsung dan diakhir kegiatan.

3. Pengarahan yang dilaksanakan oleh kepala sekolah sudah cukup baik dengan terbuktinya program-program UKS yang sudah dilaksanakan dengan baik. Beberapa program sekolah sehat dan UKS yang dilaksanakan diantaranya pembiasaan PHBS kepada seluruh warga sekolah, dalam pembiasaan ini tim UKS mencoba memasukkan materi PHBS agar menjadi budaya dalam kehidupan sehari-hari yaitu menjadi kurikulum tidak tersurat selama 5 menit di setiap mengawali pembelajaran. Selain itu aplikasinya juga dilihat setiap hari, mulai dari pemantauan kebersihan yang dilakukan oleh seluruh warga sekolah ke asrama-asrama setiap jam pulang sekolah serta di masukan nya ke dalam kegiatan kedisiplinan. Dalam pembiasaan PHBS ini banyak sekali yang di aplikasikan dari 14 tatanan di sekolah, diantarnya ; memelihara rambut agar bersih dan rapih, memakai pakaian yang bersih dan rapih, memelihara kuku, memakai sepatu bersih, berolahraga teratur, tidak merokok di sekolah, tidak menggunakan NAPZA, memberantas jentik nyamuk, menggunakan jamban yang bersih, menggunakan air bersih, mencuci tangan dengan air mengalir dan memakai sabun, membuang sampah ke tempat sampah yang terpilah, mengkonsumsi jajanan sehat dari kantin sehat sekolah, dan menimbang berat badan dan mengukur tinggi badan setiap bulan.

4. Program berikutnya yaitu melengkapi fisik UKS, program ini dimulai dengan pengadaan dan pemenuhan sarpras untuk UKS dan lingkungan sekitar. Dalam pengembangan UKS ini, khususnya UKS di SICC Boarding School, pihak sekolah mengadakan kerja sama dengan beberapa intansi terkait diantaranya; puskesmas karangtengah, Dokter Umum, Dokter gigi, PMI, Percetakan buku dan LKS, Komite Sekolah, BKBPP Kecamatan, BNN,Polsek, YKI, KPI, P4TK, LIPI, dan KPA. Selain itu juga UKS SICC membuat program-program baru untuk di terapkan di siswa, dengan berbasis kepada lingkungan, sosial, dan kemanusiaan. UKS SICC membuat program unggulan dari 4 divisi yaitu Duta Kesehatan, kegiatan yang diselenggarakan oleh duta kesehatan ini diantaranya SUNTIK (sehat tanpa jentik) ke rumah-rumah warga sekitar, dalam kegiatan ini dilakukan sekitar sebulan 2 kali. Kegiatan lainnya yaitu PLS (Penyuluhan luar sekolah), kegiatan ini diprioritaskan kepada SD yang berada di Cianjur. Program berikutnya ada Lawan anemia pada rematri (remaja putri), program ini sudah di terapkan pada bulan september 2016 lalu. SGM (sikat gigi masal) program ini untuk memicu anak jika menyikat gigi itu menyenangkan, dan program terakhir dari divisi ini yaitu gerakan 8 gelas minum air setiap hari. Divisi yang kedua yaitu duta remaja dan konselor remaja; kegiatannya seperti 10 menit memahami kesehatan reproduksi, celurit (curhat sepuluh menit) $2 \mathrm{x}$ seminggu, BBM (Berbagai bersama masyarakat) dalam hal ini sekolah memperkenalkan UKS dan budaya hidup sehat di masyarakat biasanya rutin setahun 4 kali menjelang acara milad, champion days, ramadhan, dan footsal cup. Ketiga progam dari duta go green, yaitu GPS (gerakan pungut sampah) kegiatan ini dilakukan sebulan sekali, claber (class berkebun), dilakukan oleh semua kelas dalam waktu yang tidak ditentukan. Program lainnya adalah komposting, yaitu mengolah limbah makanan dari sekolah dan kotoran kambing oleh anak KKR. Berikutnya program bank sampah, setiap kelas menabung sampah dan diuangkan untuk nanti hasil nya akan dimasukan untuk uang kas kelas, dalam kegiatan ini sekolah bekerja sama dengan bank sampah sindanglaka.

5. Program utama dari UKS sendiri yaitu TRIAS UKS, diantaranya sudah menyelenggarakan kegiatan-kegiatan sebagai berikut; 1) pendidikan kesehatan, salah satu kegiatannya seperti penyuluhan TRIAS UKS dan PHBS oleh pihak puskesmas, 2) penyuluhan TRIAD KRR (kesehatan reproduksi remaja) oleh BKBPP, 3) penyuluhan Kespro (kesehatan reproduksi) oleh Kapusbin BKBPP, 4) workshop BKR oleh tim BKBPP, 5) pembinaan materi gizi seimbang oleh programer UKS, 6) pembinaan pengelolaan lingkungan oleh Kesling puskesmas Karang tengah, 7) pembinaan KMS oleh programer UKS Kab. Cianjur. Ke delapan adalah pembinaan LSS oleh pembina yayasan, 8) bahaya rokok oleh widya Iswara dari BBPK Ciloto, 9) penyuluhan adiwiyata dan integrasi lingkungan dalam pembelajaran, 10) penyuluhan pemilahan jenis sampah oleh ketua bank sampah, 11) penyuluhan tentang kekerasan pada anak, 12) penyuluhan pencegahan kanker serviks oleh YKI, 13) penyuluhan tentang lingkungan hidup oleh KPI, 14) penyuluhan tatib lalu lintas, kenakalan remaja, dan pencegahan narkoba. Ke 14 program di atas merupakan program dari TRIAS UKS pada program pendidikan kesehatan. Pada program ke dua yaitu pelayanan kesehatan, diantaranya; pejantan (penjaringan tahunan), visitasi kepala puskesmas dan dokter rekanan, rujukan khusus dokter rekanan dan RS, sampai ke RS Hermina Sukabumi, visitasi ke asrama, pelayanan kesehatan oleh KKR, penanganan siswa/i yang sakit, pingsan dan cedera. Dan untuk program ketiga yaitu pembinaan lingkungan sekolah sehat, diantaranya kegiatan bersama (bersihkan asrama), GPS (gerakan pungut sampah), Claber (class berkebun), pertama (panen tanaman bersama), komposting, BBM (berbagi bersama masyarakat) dan SGM (sikat gigi bersama). Program-program UKS ini dapat terlaksana karena kerja sama semua pihak mulai dari peran kepala sekolah sendiri dan koordinator sekolah sehat beserta tim lainnya. 
Penerapan PHBS sendiri di SICC Boarding School sudah dilakukan di awal sekolah memiliki program sekolah sehat, memulai mensosialisasikan kepada para peserta didik di sekolah, memberikan pengarahan dan melibatkan di setiap kegiatan atau progaram-program UKS yang diselenggarakan di sekolah. Penerapan tata tertib dan peraturan tentang PHBS di informasikan juga kepada para peserta didik untuk lebih paham mengenai PHBS di sekolah. Penerapan PHBS ini dilaksanakan di semua lingkugan sekolah mulai dari kelas tempat para siswa KBM, asrama, ruang guru, kantin, halaman sekolah, perpustakaan, mesjid sekolah, lab IPA dan lab.musik. Kegiatan ini memberikan dorongan kepada para peserta didik dan para guru juga untuk membiasakan diri melakukan PHBS dilingkukan sekolah. Setiap pelaksanaan program sekolah sehat yang dijalankan di sekolah selalu terpantau secara langsung oleh kepala sekolah.

Sub Fokus 4: Pengawasan dan Pengendalian Program Sekolah Sehat.

Tahap pengendalian dalam manajemen sekolah pada program sekolah sehat di SICC Boarding School di susun secara sistematis untuk dapat mengendalikan fungsi para SDM yang ada dalam organisasi agar dapat berjalan sesuai dengan perencanaan dan tujuan yang telah ditentukan. Hal ini seperti yang di ungkapkan oleh tim dosen Administrasi Pendidikan Universitas Pendidikan Indonesia (2013:71) pengendalian melibatkan beberapa elemen yaitu 1) menetapkan standar kerja, 2) mengukur kerja, 3) membandingkan unjuk kerja dengan standar yang telah ditetapkan, 4) mengambil tindakan korektif saat terdeteksi penyimpangan.

Berdasarkan pelaksanaan manajemen sekolah yang berjalan di SICC Boarding School dalam mewujudkan sekolah sehat, maka disusun pengendalian (controlling) sebagai berikut :

1. Kegiatan pengendalian program sekolah sehat di lakukan oleh kepala sekolah sebagai ketua di struktur organisasi UKS, sehingga pengendalian program sekolah sehat dilakukan langsung oleh kepala sekolah SICC Boarding School. Dalam pelaksanaannya kepala sekolah dibantu oleh para tim sekolah sehat, koordinator sekolah sehat dan pembina UKS serta para anggota. Koordinasi tetap berjalan sesuai dengan alur di struktur organisasi. Komunikasi dari atas ke bawah terjalin dengan baik dan lancar, sehingga informasi bentuk apapun selalu tersampaikan dengan baik.

2. Acuan dilihat dari program kerja tahunan UKS yang sudah dirancang oleh koordinator sekolah sehat dan para anggota lainnya, setiap program dilihat apakah sudah dilaksanakan atau belum. Kepala sekolah melakukan evaluasi pada masingmasing program apakah dilaksanakan secara optimal sesuai dengan perencanaan awal. Selain melakukan evaluasi terhadap program sekolah sehat, kepala sekolah juga melihat seberapa jauh para personil melaksanakan tugasnya. Setiap program yang dilaksanakan dapat menjadi pembanding untuk kegiatan-kegiatan yang sudah dilaksanakan di satu tahun kebelakang. Apakah mengalami peningkatan atau penurunan, atau bahkan memiliki kendala yang lebih sulit dibanding tahun sebelumnya.

3. Pengawasan dilakukan pada hal-hal yang memang sangat penting, dalam program sekolah sehat ini hal yang utama yang mendapatkan pengawasan adalah sumber daya manusia nya itu sendiri (SDM) dan yang kedua program-program yang sudah di buat oleh koordinator sekolah sehat dan para anggota lainnya. Pengawasan pada personil dilihat dari cara bekerja dan koordinasi antar personil, apakah berjalan dengan baik atau tidak. Kepala sekolah harus memastikan bahwa setiap personil melaksanakan tugasnya dengan baik. Jika ditemukan hal-hal yang tidak sesuai dengan perencanaan dan pengorganisasian kepala sekolah dan koordinator sekolah sehat harus segera mengambil tindakan yang cepat. Hal- hal yang dapat dilakukan diantaranya melakukan pengawasan secara ketat, dan berkala agar setiap kegiatan dan program sekolah sehat yang sudah dibuat di awal selalu terpantau dan terkendali. Langkah lain dapat melakukan pengecekan program kerja sekolah sehat dan program kerja UKS yang sudah di susun di awal tahun. Pengawasan secara langsung terhadap personil dapat dilakukan oleh kepala sekolah untuk memastikan apakah setiap tugas dijalankan dengan baik. Memantau koordinasi antar personil apakah terjalin komunikasi yang baik dari pihak atas ke bawah. Kepala sekolah dapat meminta laporan dalam bentuk dokumentasi foto-foto kegiatan, pengecekan administrasi yang ada, atau pun laporan langsung dari koordinator sekolah sehat.

Kepala sekolah dalam melakukan supervisi atau evaluasi program sekolah sehat dilaksanakan tidak berdasarkan jadwal khusus, ataupun menggunakan form khusus yang dibuat kepala sekolah, namun di setiap pelaksanaan program sekolah sehat berlangsung kepala sekolahpun secara tidak langsung melakukan pengawasan. Hasil dari temuan supervisi dan pengawasan biasanya kepala sekolah akan menyampaikan kepada koordiantor sekolah sehat untuk nantinya di sampaikan ke pembina UKS dan anggota lainnya.Tujuan dari pengendalian yang dilakukan kepala sekolah adalah program UKS berjalan dengan baik sehingga kualitas mutu dari sekolah dapat terjaga. Hal ini karena menyangkut keberlangsungannya sekolah SICC Boarding School ini.

\section{SIMPULAN}

Berdasarkan analisis yang telah dilakukan terhadap data dan informasi mengenai manajemen sekolah dalam mewujudkan sekolah sehat di SICC Boarding School, maka dijabarkan kesimpulan sebagai berikut:

\section{a. Perencanaan (Planning)}

Kesimpulan yang diperoleh pada proses perencanaan sekolah sehat dalam pengembangan program sekolah sehat dan UKS menunjang keberhasilan pencapaian prestasi sekolah sehat dan sekolah dengan cara perencanaan yang khas, akurat dan menunjang konsep awal program sekolah sehat di SICC Boarding School. Perencanaan difokuskan pada penerapan PHBS semua warga sekolah, pengadaan dan pemenuhan sarpras UKS dan pelaksanaan program unggul TRIAS UKS di SICC 
Boarding School. Penentuan SDM yang tepat dalam pelaksanaan semua program kerja UKS menjadi penentu keberhasilan program. Kesiapan dari perencanaan penentuan program UKS dan SDM mengikutsertakan lomba antar sekolah, kecamatan, kabupaten dan propinsi.

\section{b. Pengorganisasian (Organizing)}

Pengorganisasian sekolah disusun berdasarkan perencanaan pengembangan program sekolah sehat. Penyusunan struktur organisasi dan pembagian tugas pada SICC Boarding School disusun ke dalam bagan struktur organisasi yang menggambarkan hirarki wewenang dari kepala sekolah (ketua) ke bawah. Masing-masing jabatan memiliki tugas dan wewenang yang jelas dan berbeda, baik secara administratif maupun capaian kinerja. Struktur organisasi terdiri dari struktur organisasi tertinggi yaitu kepala sekolah sebagai ketua dan struktur organisasi di bawahnya, yaitu koordinator sekolah sehat, pembina UKS, bendahara UKS dan anggota.

\section{c. Pelaksanaan (Actuating)}

Usaha pengarahan dilakukan oleh kepala sekolah sebagai ketua dalam rangka implementasi program sekolah sehat adalah melakukan sosialisasi visi misi UKS kepada semua warga sekolah, dilanjutkan sosialisasi konsep program sekolah sehat yang akan dilaksanakan. Dalam hal ini para personil yang terlibat di struktur organisasi menyusun program kerja tahunan UKS. Aspek pengembangan UKS menjadi konsentrasi SICC Boarding School dalam mewujudkan sekolah sehat. Adapun program unggulan UKS itu sendiri adalah TRIAS UKS. diantaranya; program pendidikan kesehatan, program pelayanan kesehatan dan pembinaan lingkungan sekolah sehat. Selain pelaksanaan program TRIAS UKS di atas, sekolah pun mengoptimalkan penerapan PHBS untuk semua warga sekolah.

\section{d. Pengendalian (Controlling)}

Pengendalian dilakukan melalui monitoring dan evaluasi. Kegiatan pengendalian dilakukan oleh kepala sekolah, di mana pengendalian dilakukan terhadap program kerja UKS, SDM maupun fasilitas UKS. Hal yang utama yang difokuskan oleh kepala sekolah dalam melakukan pengawasan yaitu dari faktor sumber daya manusianya (SDM) itu sendiri. Pengawasan yang berikutnya yaitu pada program-program yang dibuat oleh koordinator sekolah sehat dan anggota lainnya. Hal terakhir pengawasan dilakukan pada pengadaaan fasilitas penunjang sekolah sehat. Kepala sekolah memastikan untuk kelengkapan UKS apakah sudah mencapai $100 \%$ atau tidak dan mendata apakah semua fasilitas yang ada sudah sesuai dengan standar persyaratan UKS dari pemerintah atau belum sesuai.

\section{REFERENSI}

Erawan, G. N., Putri, A. S., Martiningtyas, M. A. D., Sagala, A .E. S. B., Yana, I. P. A., Martiningtyas, D., Matulu, S.,...\& Subandi. (2015). Era baru kesehatan mental Indonesia: Sebuah kisah dari desa siaga sehat jiwa (DSSJ). Jurnal Psikologi, 40(2), 169180.

Handoko, T. Hani, (2001), Manajemen Personalia dan Sumber Daya Manusia, BPFE: Yogyakarta.

Kristiawan, Muhammad dkk. (2017). Manajemen Pendidikan. Yogyakarta: CV. Budi Utama

Muhamad Mufid, 2017. Kebijakan Kepala Sekolah Tentang Program Literasi Berbasis Pendidikan Agama Islam Dan Implementasinya Dalam Upaya Meningkatkan Religiusitas Peserta Didik di SMK Bhakti Nusantara Salatiga Tahun Pelajaran 2016/2017, IAIN Salatiga.

Nugraheni, Hermien. (2018). Buku Ajar Promosi Kesehatan Berbasis Sekolah. Yogyakarta : CV. Budi Utama.

Suchyadi, Y. (2017). Relationship between Work Motivation and Organizational Culture in Enhancing Professional Attitudes of Pakuan University Lecturers. Journal of Humanities and Social Studies, 01(01).

Suryosubroto, B. (2010). Manajemen Pendidikan di Sekolah, Jakarta: PT Rineka Cipta.

Tim Dosen UPI. (2013). Adminsitrasi Pendidikan. Bandung. Alfabeta.

Yusuf, Syamsu. (2001). Psikologi Perkembangan Anak dan Remaja. Bandung. PT. Remaja Rosdakarya.

Zubaidah, Siti dkk. (2017). Evaluasi Program Sekolah Sehat di Sekolah Dasar Negeri. Jurnal Manajemen Pendidikan. Vol.4.No.1. ISSN 25499661 